\title{
Erratum to: Behavioral multi-criteria decision analysis: the TODIM method with criteria interactions
}

\author{
Luiz Flavio Autran Monteiro Gomes • \\ Maria Augusta Soares Machado • \\ Xavier Ignacio Gonzalez • Luis Alberto Duncan Rangel
}

Published online: 3 September 2013

(C) Springer Science+Business Media New York 2013

\section{Erratum to: Ann Oper Res \\ DOI 10.1007/s10479-013-1345-0}

The corresponding author would like to point out that the name of the 3rd author, Xavier Ignacio Gonzalez, was incorrectly omitted from the final article.

The online version of the original article can be found under doi:10.1007/s10479-013-1345-0.

L.F.A.M. Gomes $(\bowtie) \cdot$ M.A.S. Machado

Ibmec, Av. Presidente Wilson, 118, 11th floor, 20030-020, Rio de Janeiro, RJ, Brazil

e-mail: autran@ibmecrj.br

M.A.S. Machado

e-mail: mmachado@ibmecrj.br

\section{X.I. Gonzalez}

School of Engineering, Departamento C1127AAR, University of Buenos Aires,

Av. Las Heras 2414 Piso $1^{\circ}$, Buenos Aires, Argentina

e-mail: xavierign@gmail.com

L.A.D. Rangel

EEIMVR, UFF, Av. dos Trabalhadores, 420, 27255-125, Vila Santa Cecília, Volta Redonda, RJ, Brazil e-mail: duncan@metal.eeimvr.uff.br 